\title{
Effects of the proximity from an industrial plant on fish assemblages in the rio Paraíba do Sul, southeastern Brazil
}

\author{
Benjamin Carvalho Teixeira Pinto, Magna Galvão Peixoto and Francisco Gerson Araújo
}

This work aims to analyze changes in the fish assemblages along a longitudinal reaches of the rio Paraíba do Sul, one of the most used Brazilian aquatic systems, to assess the river "health" and to identify eventual recovery trends. Standardized monthly samplings were carried out at six sites, from October 1997 to September 1999, using casting, sieves, seine and gill nets. Three zones were searched: upstream (Z I), downstream (Z III) and nearby the source of pollution (Z II). Three univariate distribution methods were used: ABC (abundance-biomass curves), $K$-dominance curves, and geometric class's distribution. Additionally, cluster analysis was applied to detect eventual patterns. The ABC and $K$-dominance curves showed Z II with evident indication of stress in both yearly cycles, followed by Z III and Z I. Few rare species and absence of common species in Z I, presence of common and abundant species, mainly opportunist, in Z II, and the highest number of rare species in Z III, was the overall pattern showed by geometric class. Number of fish was higher at Z II, while number of species did no change significantly among zones. Cluster analysis separate Z II samples from Z I and III. All the three univariate methods showed evident signals of stress at Z II, which showed indication of organic enrichment as expressed in the high abundance of common species, although physicochemical variables (ammonia, nitrogen, total phosphorous and DBO) have increased slightly from Z1 to Z III. A lesser stress condition was shown at the downstream zone (Z III), indicating the river recovery capacity. The use of biological indicators in this study proved to be a better tool to assess non-point sources pollution when compared to traditional physicochemical measurements.

Objetiva-se no presente trabalho, analisar mudanças nas assembléias de peixes ao longo de um trecho longitudinal do rio Paraíba do Sul, um dos sistemas aquáticos mais usados do Brasil, para avaliar a "saúde" do rio e identificar eventuais tendências de recuperação. Amostragens mensais foram realizadas em seis locais, de outubro de 1997 a setembro de 1999 , utilizando redes de espera, tarrafas, peneiras e picaré. Foram atribuídas três zonas para avaliar as assembléias de peixes: Z II (complexo industrial da cidade de Volta Redonda - fonte da poluição), Z I (montante do complexo industrial) e Z III (jusante do complexo industrial). Três métodos univariados foram usados: ABC (curvas de abundância-biomassa), curvas de $K$-dominância, e distribuição por classes geométricas. Adicionalmente, foram aplicadas análises de agrupamento para verificar padrões de distribuição das espécies. A curva ABC e a curva de $K$-dominância indicaram maior estresse para a Z II, em ambos os ciclos anuais seguido pelas Z III e I. A classe geométrica apresentou um padrão de poucas espécies raras e ausência de espécies comuns para a Z I, presença de espécies comuns e abundância de espécies oportunistas para a Z II, e maior número de espécies raras na Z III. O número de indivíduos foi maior na Zona II, enquanto o número de espécies não teve variação significativa entre as zonas. A análise de agrupamento separou as amostras da Z II das Z I e III. Todos os três métodos utilizados no presente trabalho apresentaram maior número de espécies comuns para a Z II, indicando maior estresse para Z II, zona que recebe maior carga de efluentes de origem orgânica e industrial. Uma melhor condição foi apresentada para o trecho mais a jusante (Z III), indicando a capacidade de recuperação do rio. O uso de indicadores biológicos neste estudo provou ser uma melhor ferramenta para avaliar poluição difusa quando comparada com métodos físico-químicos tradicionais.

Key words: Fish community, Neotropical fauna, Pollution, Water quality, ABC curves, Cluster analysis.

\section{Introduction}

Large rivers in southeastern Brazil are under increasing degradation process from misuse, being strongly influenced by human activity yielding detrimental ecological effects. The rio Paraíba do Sul is one of the most used lotic systems in the country because its proximity to the major industrial and urban Brazilian centers, and its water is widely used for both

Universidade Federal Rural do Rio de Janeiro, Laboratório de Ecologia de Peixes, Km 47, Antiga Rodovia Rio - São Paulo, $23851-970$ Seropédica, Rio de Janeiro, Brazil. e-mail: (BCTP) benjamin@ufrrj.br; (FGA) gerson@ufrrj.br 
domestic and industrial purposes. The most used reaches of the Paraíba do Sul river is located in its middle-lower segment, due to a major industrial plant (Pfeiffer et al., 1986), which carries into the river a large amount of non-point source pollution from both organic and inorganic pollutants; some $20 \mathrm{Km}$ downstream this point there is the intake pump water to hydropower uses and, afterward, to the Rio de Janeiro city water supplier. Concerns of populations and environmental managers have being raised as result of the decreased water quality and poor habitat condition, which has decreased water flow in the last years (Hydroscience, 1977).

The use of biota to assess the anthropogenic impacts on the integrity of rivers is attaining greater importance (Miller et al., 1988; Rosenberg \& Rech, 1993; Scott \& Hall, 1997; Gafny et al., 2000; Hughes, 2000; Karr et al., 2000). Assessing fish community structure is one efficient way to evaluate biotic integrity in rivers in different parts of the world (Karr, 1981; Karr, 1986; Edds, 1993; Paller et al., 1996; Ganasan \& Hughes, 1998; Waite \& Carpenter, 2000; Meador \& Goldstein, 2003) since complex biotic and abiotic processes can reflect a variety of activities developed by the man, which can change fish structure and composition. Many studies linking fish community structure and environmental degradation as result of anthropogenic influences, such as agriculture and urbanization are available (Klein, 1979; Goldstein, 1981; Karr et al., 1985; Steedman, 1988; Roth et al., 1996; Lammers \& Allan, 1999; Schlieger, 2000; Waite \& Carpenter, 2000; Meador \& Goldstein, 2003). Fish community composition changes are important tool to characterize environmental quality. For instance, the number of individuals can be used to reflect the biomass and energy in the system, while the species number to reflect habitat diversity and fish behavior.

Some researches have been carried out attempting to detect fish changes as result of environmental deterioration in the rio Paraíba do Sul. Araújo (1983) and Pfeiffer et al. (1986) found heavy metal traces in several fish species in the area near to the Volta Redonda municipality in the middle-lower segment; Araújo (1996) and Araújo et al. (2001) described the fish community composition and reported that there is a decreased abundance although richness were not very depressed yet; Araújo (1998) and Araújo et al. (2003) applying the Index of Biotic Integrity - IBI in a narrow reaches of the Paraíba do Sul river (c.a. $80 \mathrm{~km}$ ), and found that the lowest quality in fish assemblages occurred near to cities that receives large amount of organic and industrial pollutants.

Three univariate methods (abundance-biomass curves, $\mathrm{K}$-dominance curves and number of species per geometric classes) were developed to evaluate the ecological "health" (sensu Norris \& Thoms, 1999) with emphasis to benthic macrofauna (Gray et al., 1988; Gray, 1989; Warwick \& Clarke, 1991; Pagola-Carte, 2004); these methods seek to assess the degree of stress caused by pollutants. Adaptations of these methods for fish community have been performed by Andrews \& Rickard (1980), García et al. (1998), Araújo et al. (2000) and Bervoets et al. (2005), among others.

The aim of this paper is to assess the ecological "health" in the most polluted reaches of the rio Paraíba do Sul and to identify eventual recovery trends. For that purpose we used fish assemblage structure as an indicator of environmental condition. We compare the structure of the fish assemblages in three sections (zones) of the river where we expected to evaluate the extent of the pollution impact. Ecosystem perturbation such as enrichment with organic matter is expected to reduce species richness and enhance abundance of opportunist's species. The underlying hypothesis is that environmental condition influence fish assemblages.

\section{Materials and Methods}

Study area and sampling. The rio Paraíba do Sul is $1080 \mathrm{~km}$ long, with its drainage basin covering an area of approximately $57,000 \mathrm{~km}^{2}$, draining into the Atlantic Ocean at Southeast Brazil. The study area (Fig. 1) is an $80 \mathrm{~km}$ long reaches (Latitude: $22^{\circ} 24^{\prime}-22^{\circ} 25^{\prime} \mathrm{S}$; Longitude: $44^{\circ} 16^{\prime} \mathrm{W}-43^{\circ} 43^{\prime} \mathrm{W}$ ), in the Middle-Lower reaches. The middle reach of the rio Paraíba do Sul flows 400 to $600 \mathrm{~m}$ above sea level and drains ancient, predominantly sedimentary, soil covered by tropical forest. This ecoregion is characterized by both un- and semi-consolidated sand, gravel, silt and clay, with basalt outcroppings, low mountains, low nutrient soils, fragmented semi-deciduous seasonal rain forest, and poor croplands. The climate is mesothermic with high relative humidity, hot and wet summers and dry winters. Annual rainfall ranges from 100-300 $\mathrm{cm}$, with the average generally over $200 \mathrm{~cm}$ (DNAEE, 1983). Most precipitation occurs between November and January, and heavy rains occasionally cause large floods of the rio Paraíba do Sul. June through August is the driest period of the year (Carvalho \& Torres, 2002). Temperature ranges from the minimum of $20-22^{\circ} \mathrm{C}$ in June through August and maximum of $32-34^{\circ} \mathrm{C}$ in December through February, with an annual average of $26-28^{\circ}$.

River flow in this reach averages $318 \mathrm{~m}^{3} \mathrm{~s}^{-1}$, ranging from $109 \mathrm{~m}^{3} \mathrm{~s}^{-1}$ in the dry period to $950 \mathrm{~m}^{3} \mathrm{~s}^{-1}$ in the wet period (Hydroscience, 1977). The rio Paraíba do Sul waters are widely used for human consumption, industrial use, irrigation, hydroelectric power plants and recreation. The total water volume removed for domestic uses is estimated at $160 \mathrm{~m}^{3} \mathrm{~s}^{-1}$; other uses like industry and agriculture lack official volume estimates (Carvalho \& Torres, 2002). Human actions at the landscape scale disrupt the geomorphic processes that maintain the riverscape and its associated biota and frequently result in habitat that is both degraded and less heterogeneous. Aloctone material carrying into the river is favored, mainly in rainy period, due the rare vegetal cover.

The study reaches was chosen because it drains one of the most important industrial regions in Brazil, and includes the most polluted reaches of the river (Pfeiffer et al., 1986), with several textile, chemical and food industries, and a large industrial plant (steel) at Volta Redonda municipality. Agriculture and sand mining are also common in the area. We divided the longitudinal river reaches in three sections, according to the proximity of the major industrial plant in Volta 
Redonda municipality: Zone I (Z I) - a relatively less perturbed section in the upper reaches near to Porto Real (site 1) and Barra Mansa (site 2) municipalities; Zone II (Z II) - near to the highest impacted area, in the vicinity of Volta Redonda (sites 3 and 4) industrial plant; and Zone III (Z III) - the lowest section, about $20 \mathrm{~km}$ below Volta Redonda, located in Barra do Piraí (sites 5 and 6) municipality.

Monthly sampling was carried out at the 6 sites in the three river zones (Fig. 1), from October 1997 to September 1999. River morphometry (width ca. $200 \mathrm{~m}$ ) was similar at all sites. Several standardized fishing methods were used to collect the maximum number of species and individuals in different sizes and microhabitats. Fishing equipment included gill nets, cast nets, seines and sieves. Sampling unit was the sum of the total number of fish catched by 15 casting nets, 20 sieves and 2 seines tries, with fishing being conducted at daytime. Seine net were $10 \mathrm{~m}$ long, $2 \mathrm{~m}$ height, and $5 \mathrm{~mm}$ mesh size; sieves were $80 \mathrm{~cm}$ diameter and $3 \mathrm{~mm}$ mesh size; casting net were $4 \mathrm{~m}$ diameter and $2 \mathrm{~cm}$ mesh size.

All fishes were identified, counted and weighted (in g), being fixed in $10 \%$ formalin for two days, and then preserved in $70 \%$ alcohol. Voucher specimens were deposited in the fish collection of the Laboratory of Fish Ecology, Universidade Federal Rural do Rio de Janeiro.

Physicochemical variables. Temperature (degrees Celsius), transparency $(\mathrm{cm})$, turbidity (UNT), $\mathrm{pH}$, dissolved oxygen $(\mathrm{mg} / \mathrm{l})$ and conductivity $(\mu \mathrm{S} / \mathrm{cm}))$ were taken at each sampling occasion using a multiprobe water quality checker HORIBA U-10. Additionally a water quality database comprising information on ammonia, nitrogen, total phosphorous, BOD and benzo-alpha-phyrene from each sampling site during 1997-99 was supplied by the Laboratory of Hydrology from COPPEUFRJ.

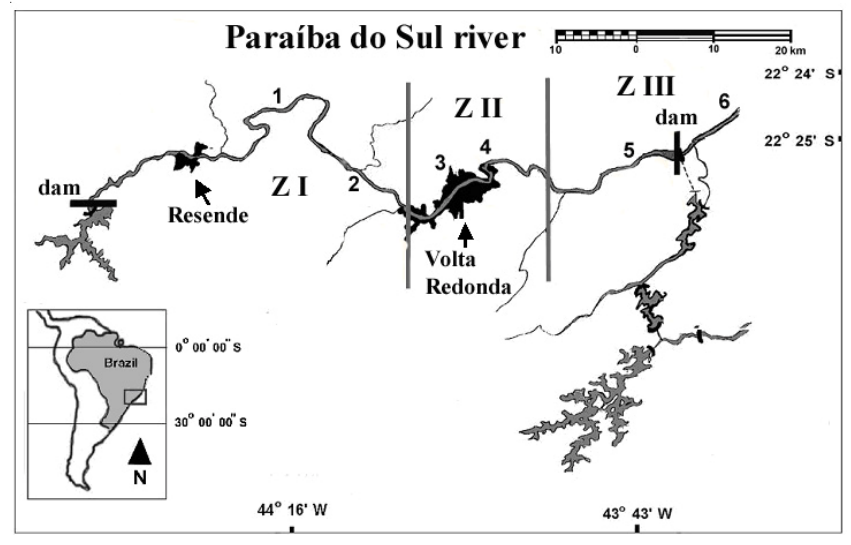

Fig. 1. Study area, rio Paraíba do Sul reaches. Indication of the six sampling sites and three zones - Z I (sites 1 and 2); Z II (sites: 3 and 4); and Z III (sites 5 and 6). Buffers marked in black indicate main sources of urban and industrial pollution. Dams indicated by black line marks.
Fish community assessment. Three distributional univariate methods were used: ABC curves (abundance-biomass curves), K-dominance curves and distribution per geometric classes. The ABC curves followed Warwick (1986) while the k-dominance curves followed Lambshead et al. (1983). We use these two curves because according to Warwick (1986) the condition of an animal community can be illustrated with the use of combined $k$-dominance plots of the abundance and biomass, where species are ranked in order of importance on the $\mathrm{x}$-axis (logarithmic scale) with percentage dominance on the $y$-scale (cumulative scale). To compare data sets from the three zones the $\mathrm{ABC}$-index was calculated according to Meire \& Dereu (1990):

$$
\text { ABC index }=\frac{\sum_{i=1}^{N} B_{i}-A_{i}}{N}
$$

where $B i$ is the percentage dominance of species $i$ (ranked from the highest to the lowest biomass) and $A i$ is the percentage dominance of species $i$ (ranked from the most to the least abundant species), and $N$ is the total number of species. The index is negative for situations characterized by a strong stress, close to zero for moderate stress, and positive for lack of stress (Meire \& Dereu, 1990; Coeck et al., 1993). Species abundance patterns, presented as the number of species in $\mathrm{x}$ 2 geometric classes (1, 2-3, 4-7, 8-15, etc.) were plotted following Gray \& Pearson (1982).

An additional cluster analysis in mode $\mathrm{Q}$ was applied to sampling sites in order to seek patterns, where Bray-Curtis distance and Ward method of clustering were applied using the FITOPAC software computer program developed by Shepherd (2001).

\section{Results}

Environmental variables. General water quality characteristics of the different sampling zones are summarized in Table 1. These results clearly show that all sites had good water quality characteristics, when compared with national and international water quality standards (Brazilin Environmental Council - CONAMA resolution n ${ }^{\circ} 20$ of 06/18/1986; Environmental Protection Agency, 1999). Ammonia, nitrogen, total phosphorous and DBO showed a trend for increased values from $Z \mathrm{I}$ to $\mathrm{Z}$ III. The $\mathrm{pH}$ was higher at $\mathrm{Z}$ II, while transparency decreased from Z I to Z III, showing an opposite pattern compared with turbidity. Conductivity was higher in $\mathrm{Z} 1$ and lower in Z II.

Species composition. A total of 7286 individuals comprised in 15 families and 51 species were catched (Table 2). The Ostariophysi superorder amounted to $76 \%$, while Acanthopterygii, $24 \%$ of the total number of species, being the former comprised mainly by Characiformes $(41.18 \%)$ and Siluriformes (29.41\%). Characidae family showed the most richness amounting to $29.41 \%$ of total number of species, followed by Cichlidae (13.73\%). 
Introduced species comprised $15.7 \%$ of the total number of species, being 5 exotic in Cichlidae (genera Oreochromis and Tilapia) and Poeciliidae (Poecilia reticulata) families, and the other 3 allochthonous (Cichla monoculus, Hyphessobrycon eques, and Metynnis maculatus) (Table 2).

Total number of fish was the highest in Z II and the lowest at Z I in both periods (1997/98 and 1998/99) (Table 3). Number of species did not vary much among the zones but tended to be the highest at Z III and the lowest at Z I. The most abundant species were Poecilia reticulata and Geophagus brasiliensis amounted to $39.7 \%$ and $27.4 \%$ of the total number fish, respectively. These two opportunist species plus Tilapia sp. predominated in Z II. Nineteen species were distributed in the three zones, while twenty-nine species contributed less than $1 \%$ to the total number of fish, with 10 being recorded only once during the two yearly period (Table 3 ).

Effects of environmental stress on the three zones. The $\mathrm{ABC}$ curves showed that Z II was the most stressed section in both yearly periods, with the abundance curve lying near to the

Table 1. Means \pm standard error for water quality characteristics in the three sampled zones of the rio Paraíba do Sul, 1997/99. Dates indicated by a slash correspond to the two yearly periods: $1997-98 / 1998-99 . n=$ number of samples. $\mathrm{ND}=$ not available. *Data supplied by the Laboratory of Hydrology from COPPE-UFRJ.

\begin{tabular}{lccc}
\hline \multicolumn{1}{c}{ Physicochemical variables } & Z I & Z II & Z III \\
\hline Transparency $(\mathrm{cm})$ & $44 \pm 0.03 / 39 \pm 0.03 \mathrm{n}=24$ & $44 \pm 0.02 / 44 \pm 0.38 \mathrm{n}=24$ & $41 \pm 0.03 / 40 \pm 0.03 \mathrm{n}=24$ \\
Turbidity $(\mathrm{UNT})$ & $48 \pm 5.10 / 58 \pm 10.46 \mathrm{n}=21$ & $59 \pm 15.10 / 38 \pm 4.44 \mathrm{n}=22$ & $69 \pm 13.13 / 35 \pm 5.46 \mathrm{n}=22$ \\
Temperature $\left({ }^{\circ} \mathrm{C}\right)$ & $22.94 \pm 0.70 / 22.23 \pm 0.52 \mathrm{n}=24$ & $25.25 \pm 1.33 / 23.04 \pm 0.51 \mathrm{n}=24$ & $23.82 \pm 0.75 / 23.38 \pm 0.55 \mathrm{~N}=24$ \\
$\mathrm{pH}$ & $6.89 \pm 0.24 / 6.53 \pm 0.21 \mathrm{n}=24$ & $7.67 \pm 0.43 / 7.20 \pm 0.20 \mathrm{n}=24$ & $7.59 \pm 0.16 / 7.15 \pm 0.16 \mathrm{n}=24$ \\
Conductivity $(\mu \mathrm{S} / \mathrm{cm})$ & $85 \pm 0.04 / 84 \pm 0.01 \mathrm{n}=24$ & $57 \pm 0.01 / 69 \pm 0.01 \mathrm{n}=24$ & $66 \pm 0.02 / 68 \pm 0.01 \mathrm{n}=24$ \\
Dissolved oxygen $(\mathrm{mg} / \mathrm{L})$ & $6.69 \pm 0.40 \mathrm{n}=9$ & $6.90 \pm 0.17 \mathrm{n}=9$ & $7.06 \pm 0.11 \mathrm{n}=9$ \\
Ammonia * $(\mathrm{mg} / \mathrm{l})$ & $0.06 \pm 0.01 \mathrm{n}=5$ & $0.06 \pm 0.01 \mathrm{n}=11$ & $0.14 \pm 0.02 \mathrm{n}=5$ \\
Nitrogen * $(\mathrm{mg} / \mathrm{l})$ & $0.47 \pm 0.09 \mathrm{n}=5$ & $0.54 \pm 0.01 \mathrm{n}=11$ & $0.63 \pm 0.21 \mathrm{n}=4$ \\
Total Phosphorus * $(\mathrm{mg} / \mathrm{l})$ & $0.08 \pm 0.02 \mathrm{n}=5$ & $0.11 \pm 0.02 \mathrm{n}=10$ & $0.12 \pm 0.02 \mathrm{n}=5$ \\
DBO * $(\mathrm{mg} / \mathrm{l})$ & $2.18 \pm 0.13 \mathrm{n}=9$ & $2.13 \pm 0.05 \mathrm{n}=15$ & $2.40 \pm 0.23 \mathrm{n}=9$ \\
Benzo-alpha-phyrene * $(\mu \mathrm{g} / \mathrm{l})$ & $\mathrm{ND}$ & $0.12 \pm 0.08 \mathrm{n}=2$ & $0.04 \pm 0.01 \mathrm{n}=9$ \\
\hline
\end{tabular}

Table 2. Fish species collected in the rio Paraíba do Sul, from 1997/99. Species are listed following Reis et. al. (2003).

\begin{tabular}{|c|c|}
\hline Superorder Ostariophysi & Order Siluriformes (cont.) \\
\hline Order Characiformes & Family Callichthyidae \\
\hline Family Characidae & Callichthys callichthys (Linnaeus, 1758) \\
\hline Astyanax bimaculatus (Linnaeus, 1758) & Corydoras nattereri Steindachner, 1877 \\
\hline Astyanax parahybae (Eigenmann, 1908) & Family Loricariidae \\
\hline Astyanax giton Eigenmann, 1908 & Hypostomus affinis (Steindachner, 1877) \\
\hline Astyanax scabripinnis (Jenyns, 1842) & Hypostomus auroguttatus Kner, 1854 \\
\hline Astyanax sp. 1 Baird e Girard, 1854 & Hypostomus sp. Lacépede, 1803 \\
\hline Astyanax sp. 2 Baird e Girard, 1854 & Loricariichthys castaneus (Castelnau, 1855) \\
\hline Astyanax taeniatus (Jenyns,1842) & Harttia loricariformis Steindachner, 1877 \\
\hline Deuterodon sp. 1 Eigenmann, 1907 & Rineloricaria sp. Bleeker, 1862 \\
\hline Deuterodon sp. 2 Eigenmann, 1907 & Order Gymnotiformes \\
\hline Hyphessobrycon bifasciatus Ellis, 1911 & Family Gymnotidae \\
\hline Hyphessobrycon reticulatus Ellis, 1911 & Gymnotus cf. carapo Linnaeus, 1758 \\
\hline Hyphessobrycon eques (Steindachner 1882) & Gymnotus sp. Linnaeus, 1758 \\
\hline Metynnis maculatus (Kner, 1858) & Family Sternopygidae \\
\hline Oligosarcus hepsetus (Cuvier, 1829) & Eigenmannia virescens (Valenciennes, 1842) \\
\hline Probolodus heterostomus Eigenmann, 1911 & Superorder Acanthopterygii \\
\hline Family Erythrinidae & Order Synbranchiformes \\
\hline Hoplias malabaricus (Bloch, 1794) & Family Synbranchidae \\
\hline Hoplerythrinus unitaeniatus (Agassiz, 1829) & Synbranchus marmoratus Bloch, 1795 \\
\hline Family Curimatidae & Order Cyprinodontiformes \\
\hline Cyphocharax gilbert (Quoy e Gaimard, 1824) & Family Poecilidae \\
\hline Family Anostominae & Phalloceros caudimaculatus (Hensel, 1868) \\
\hline Leporinus copelandii Steindachner, 1875 & Poecilia reticulata (Peters, 1859) \\
\hline Leporinus mormyrops Steindachner, 1875 & Order Perciformes \\
\hline Leporinus sp. Spix \& Agassiz, 1829 & Family Sciaenidae \\
\hline Order Siluriformes & Pachyurus adspersus Steindachner, 1879 \\
\hline Family Auchenipteridae & Family Cichlidae \\
\hline Glanidium albescens Lütken, 1874 & Australoheros facetum (Jenyns, 1842) \\
\hline Trachelyopterus striatulus (Steindachner, 1877) & Cichla monoculus Spix \& Agassiz, 1831 \\
\hline Family Pimelodidae & Crenicichla lacustris (Castelnau, 1855) \\
\hline Pimelodus maculatus La Cepède, 1803 & Geophagus brasiliensis (Quoy \& Gaimard, 1824) \\
\hline Pimelodus fur (Lütken, 1874) & Tilapia rendalli (Boulenger, 1897) \\
\hline Family Heptapteridae & Oreochromis niloticus niloticus (Linnaeus, 1758) \\
\hline Pimelodella sp. Eigenmann \& Eigenmann, 1888 & Oreochromis sp. Gunther, 1862 \\
\hline Rhamdia quelen (Quoy \& Gaimard, 1824) & Tilapia - hybrid $O$. Mossambicus (Peters, 1844 - male) vs. $O$ \\
\hline Rhamdella sp. Eigenmann \& Eigenmann, 1888 & niloticus niloticus (Linnaeus, 1758 - female) \\
\hline
\end{tabular}


biomass curve consistently; the ABC-index was close to zero in 1997/98 and negative in 1998/99 (Fig. 2). The biomass curve showed higher cumulative values when compared with abundance curve in 1997/98, and lied more closely in 1998/99 for Z I. The opposition situation was shown for Z III, with abundance and biomass curves lying near each other in 1997/98 and lying father apart in 1998/99. The ABC-index values were positive for $\mathrm{Z}$ I and III in both periods with higher values for Z I. Therefore Z II was the worse situation followed by Z III, while Z I showed the best situation (Fig. 2), according to ABC curves.

The $K$-dominance curves (Fig. 3 ) showed a similar pattern when compared with the ABC curves, with Z II showing a few highly dominant species in both periods. In 1997/98 the kdominance curves for Z II and III were closely coincident, while in 1998/98, Z I and III curves coincided closely and differed from Z II.
In relation the geometric class (Fig. 4), Z I showed few rare species and absence of high abundant common species; Z II showed higher number of rare species than Z I, but was dominated by a few number of extremely abundant species (opportunist species); Z III showed the highest number of rare species, but was dominated by common species.

Cluster analysis showed for both yearly periods a clear separation among the zones. In 1997/98 (Fig. 5), cluster 2 and 3 showed samples mainly from Z II, while cluster 1 showed samples from Z I and III. In 1998/99 (Fig. 6) this separation was more consistent, with cluster analysis showing three groups; cluster 3 was formed mainly by Z II samples (most stressed zone) while clusters 1 and 2 were formed by $Z$ I and III samples. Cofenetic correlation was 0.46 for $1997 / 98$ and 0.57 for $1998 / 99$ indicating a better separation in the latter period but a still high number of species distributed all over the three zones.

Table 3. Total number of individuals by species per zones during the two sampling cycles (1997/1999) in the rio Paraíba do Sul.

\begin{tabular}{|c|c|c|c|c|c|c|c|c|}
\hline \multirow[t]{2}{*}{ Species } & \multicolumn{2}{|c|}{ Z I } & \multicolumn{2}{|c|}{ Z II } & \multicolumn{2}{|c|}{ Z III } & \multirow[t]{2}{*}{ Total } & \multirow[t]{2}{*}{$\%$} \\
\hline & $1997 / 98$ & $1998 / 99$ & $1997 / 98$ & $1998 / 99$ & $1997 / 98$ & $1998 / 99$ & & \\
\hline Poecilia reticulata & 19 & 16 & 607 & 551 & 43 & 97 & 1333 & 39.7 \\
\hline Geophagus brasiliensis & 24 & 43 & 404 & 117 & 112 & 220 & 920 & 27.4 \\
\hline Tilapia sp. & 0 & 1 & 6 & 178 & 0 & 8 & 193 & 5.7 \\
\hline Phalloceros caudimaculatus & 4 & 3 & 5 & 2 & 61 & 3 & 118 & 3.5 \\
\hline Rineloricaria sp. & 5 & 2 & 24 & 19 & 24 & 16 & 90 & 2.7 \\
\hline Astyanax giton & 7 & 2 & 8 & 36 & 12 & 21 & 86 & 2.5 \\
\hline Tilapia rendalli & 0 & 0 & 48 & 16 & 5 & 5 & 74 & 2.2 \\
\hline Astyanax sp. 1 & 10 & 5 & 28 & 6 & 12 & 12 & 73 & 2.2 \\
\hline Astyanax bimaculatus & 4 & 31 & 0 & 5 & 10 & 15 & 65 & 1.9 \\
\hline Astyanax parahybae & 4 & 34 & 0 & 19 & 0 & 6 & 63 & 1.9 \\
\hline Astyanax sp. 2 & 1 & 8 & 19 & 4 & 1 & 10 & 43 & 1.3 \\
\hline Oligosarcus hepsetus & 2 & 7 & 1 & 4 & 9 & 13 & 36 & 1.1 \\
\hline Pimelodus maculatus & 6 & 12 & 4 & 12 & 0 & 1 & 35 & 1.0 \\
\hline Deuterodon sp. 1 & 0 & 2 & 0 & 1 & 10 & 19 & 32 & 0.9 \\
\hline Hyphessobrycon reticulatus & 0 & 0 & 0 & 0 & 0 & 24 & 24 & 0.7 \\
\hline Oreochromis niloticus niloticus & 0 & 0 & 20 & 1 & 2 & 0 & 23 & 0.7 \\
\hline Hypostomus sp. & 4 & 2 & 6 & 4 & 1 & 3 & 20 & 0.6 \\
\hline Corydoras nattereri & 0 & 0 & 0 & 0 & 8 & 11 & 19 & 0.6 \\
\hline Hyphessobrycon egues & 0 & 4 & 0 & 1 & 2 & 12 & 19 & 0.6 \\
\hline Astyanax scabripinnis & 2 & 1 & 1 & 0 & 0 & 7 & 11 & 0.3 \\
\hline Hoplias malabaricus & 1 & 5 & 2 & 1 & 1 & 1 & 11 & 0.3 \\
\hline Leporinus copelandii & 9 & 0 & 1 & 0 & 1 & 0 & 11 & 0.3 \\
\hline Callichthys callichthys & 0 & 0 & 0 & 5 & 1 & 3 & 9 & 0.3 \\
\hline Hypostomus auroguttatus & 0 & 0 & 9 & 0 & 0 & 0 & 9 & 0.3 \\
\hline Hypostomus affinis & 1 & 0 & 7 & 1 & 0 & 0 & 9 & 0.3 \\
\hline Probolodus heterostomus & 4 & 4 & 0 & 0 & 0 & 1 & 9 & 0.3 \\
\hline Gymnotus cf. carapo & 0 & 2 & 1 & 0 & 0 & 1 & 4 & 0.1 \\
\hline Rhamdia sp. & 0 & 0 & 0 & 0 & 2 & 2 & 4 & 0.1 \\
\hline Hyphessobrycon bifasciatus & 0 & 0 & 1 & 0 & 1 & 1 & 3 & 0.1 \\
\hline Tilápia vermelha & 0 & 0 & 2 & 1 & 0 & 0 & 3 & 0.1 \\
\hline Leporinus sp. & 0 & 0 & 2 & 0 & 0 & 0 & 2 & $<0.1$ \\
\hline Crenicichla lacustris & 1 & 0 & 1 & 0 & 0 & 0 & 2 & $<0.1$ \\
\hline Cichla monoculus & 0 & 1 & 0 & 0 & 0 & 0 & 1 & $<0.1$ \\
\hline Australoheros facetum & 0 & 0 & 0 & 1 & 0 & 0 & 1 & $<0.1$ \\
\hline Cyphocharax gilbert & 0 & 0 & 0 & 0 & 0 & 1 & 1 & $<0.1$ \\
\hline Gymnotus sp. & 0 & 0 & 0 & 0 & 0 & 1 & 1 & $<0.1$ \\
\hline Hoplerythrinus unitaeniatus & 0 & 0 & 0 & 0 & 1 & 0 & 1 & $<0.1$ \\
\hline Leporinus mormyrops & 0 & 1 & 0 & 0 & 0 & 0 & 1 & $<0.1$ \\
\hline Loricariichthys castaneus & 0 & 0 & 1 & 0 & 0 & 0 & 1 & $<0.1$ \\
\hline Pimelodella $\mathrm{sp}$. & 0 & 0 & 0 & 0 & 1 & 0 & 1 & $<0.1$ \\
\hline Total number of fishes & 108 & 186 & 1208 & 985 & 320 & 554 & 3361 & 100.0 \\
\hline Total number of species & 18 & 21 & 24 & 22 & 22 & 27 & & \\
\hline
\end{tabular}




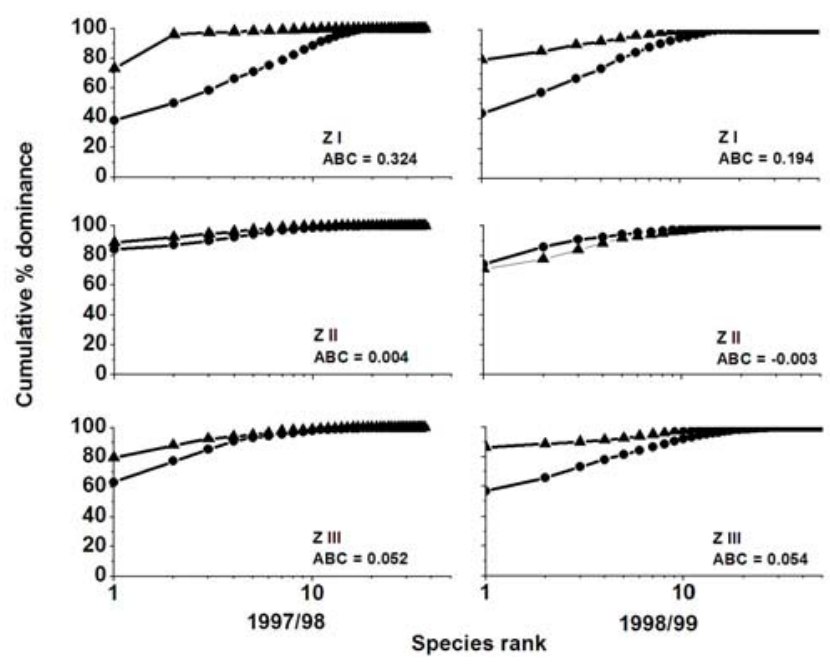

Fig. 2. ABC curves for fish species in the three zones of the rio Paraíba do Sul, in 1997/99. Round marks - abundance; triangle marks - biomass. $\mathrm{ABC}$-indexes indicated for each zone.

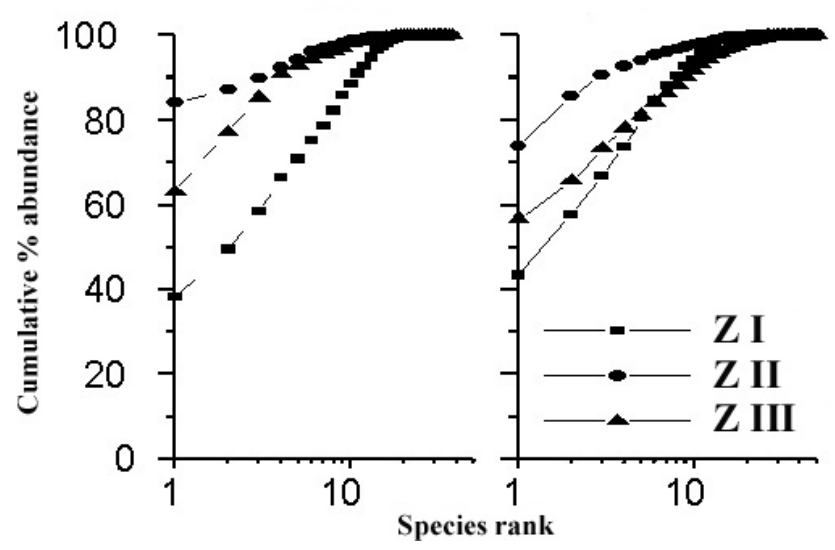

Fig. 3. K-dominance curves for the fish species in the three zones of the rio Paraíba do Sul, in 1997/99.

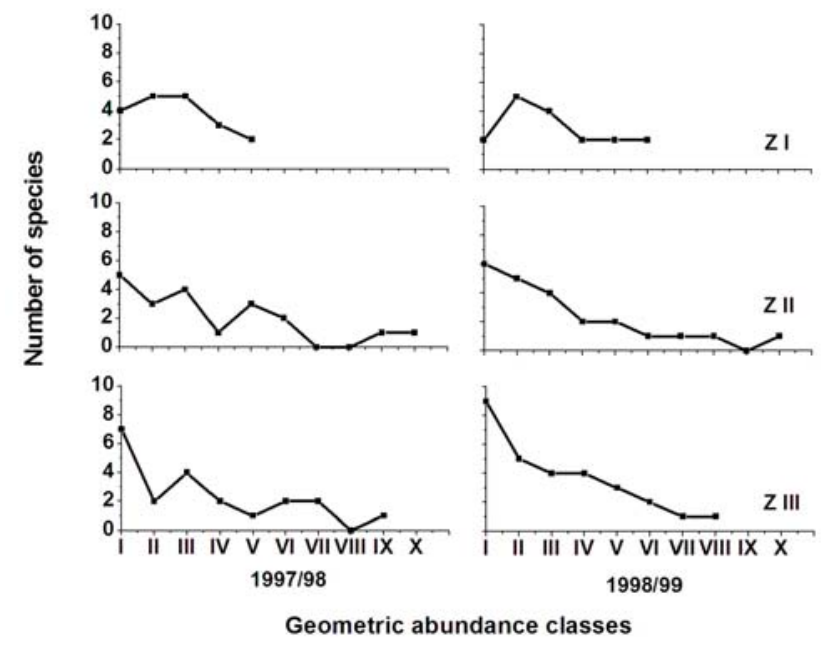

Fig. 4. Number of species per geometric classes (x 2) in the three zones of the rio Paraíba do Sul, in 1997/99.

\section{Discussion}

Overall water quality characteristics were acceptable for all zones and no indication of acute pollution was detected. Levels of measured environmental variables are well within the expected values for rivers of Class 2 according to CONAMA resolution, which states that such water should be suitable for domestic supply, after conventional treatment, being good for aquatic communities, aquaculture and other similar uses. Although the study area encompass a major urbanized and industrialized river reaches, which is considered the most impacted segment of the rio Paraíba do Sul watershed (Pfeiffer et al., 1986; FEEMA, 1987), the physicochemical water quality measurements did not confirm this statement. According to the records there is a trend for slightly worse condition at Z III and a comparatively better condition at Z I. This relatively good water quality can be explained by high dilution capacity of this river reaches; additionally water samples were collected from the main channel, not near to effluent entrance. According to Pratt \& Coler (1976) no trend can be detected when water samples are taken far from pollutants sources and sites of discharges near to the river margins.

The fish assemblages in the rio Paraíba do Sul is comprised mainly by species adapted to altered environments such as Poecilia reticulata, Geophagus brasiliensis and Tilapia $\mathrm{sp}$., which are opportunists ones, commonly associated to organic enrichment; these species take advantage of large organics loads from Municipal discharges and other industrial pollutants sources. High abundances of opportunist species in impacted environments have been reported in the current literature (Fausch et al., 1990; Ganasan \& Hughes, 1998; Soto-Galera et al., 1998). Ganasan \& Hughes (1998) reported that sites in a major degraded area in the Khan river near to Indore City in India, were comprised mainly by three tolerant species: Poecilia reticulata, Channa punctatus and Diaphus dumerili. Odum (1969) reported that specialist species are quickly replaced by opportunists ones when there is environmental alteration. Rougharden (1974) stated that generalist species show advantage over the specialists in case of deterioration. Krebs $(1985 ; 1994)$ associated low species abundance to limited food availability and reported that balanced communities show stable species abundance. Winemiller (1995) reported that other parameters associated with life history such as taxonomic diversity local, biogeographic events and biotic interactions should be considered in order to have a more complete picture of the fish assemblage composition.

The three univariate methods used to assess environmental influences on ichthyofauna ( $\mathrm{ABC}$ curves, $\mathrm{k}$-dominance curves and geometric class species distribution) are in close agreement with each other. They showed a clear gradient in the level of disturbance across the zones, with a more stressed situation near to the industrial plant at Z II. The industrial plant at Volta Redonda municipality is undoubtedly a major source of alteration on the rio Paraíba do Sul, being comprised by several industries such as steel, pesticides and 


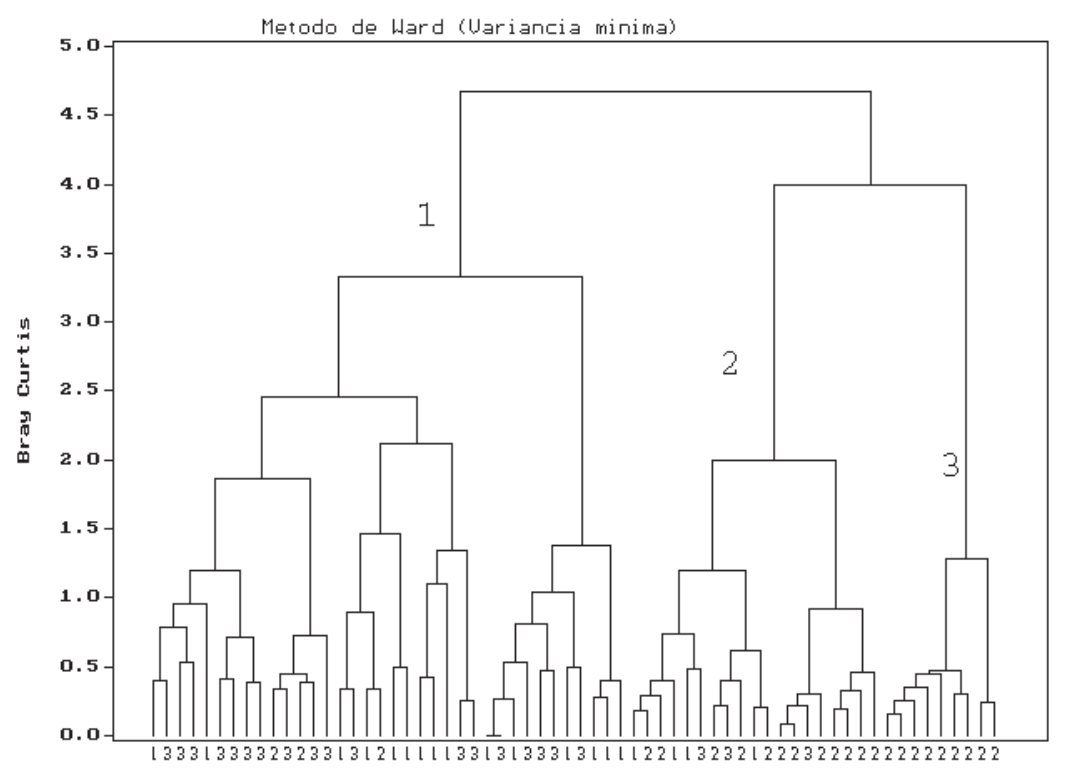

Fig. 5. Cluster analysis of fish abundance on mode Q, showing the three zones in the Paraíba do Sul river, in 1997/98. In $x$-axis $=1:$ Z I; 2: Z II; 3: Z III.

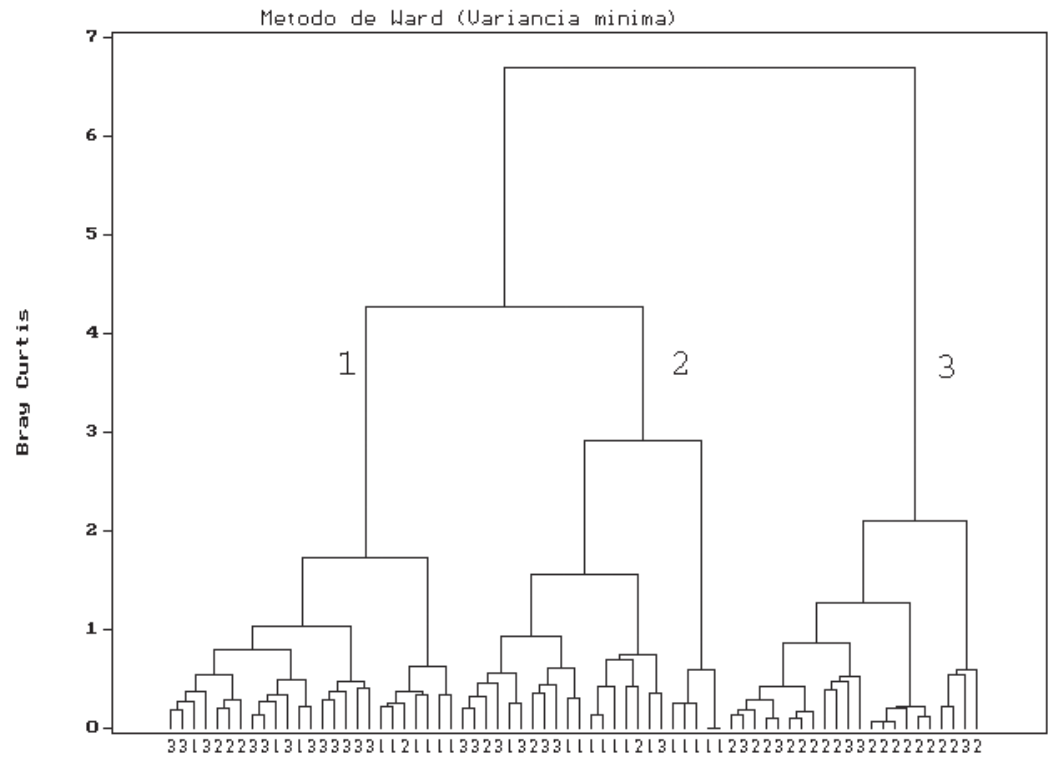

Fig. 6. Cluster analysis of fish abundance on mode Q, showing the three zones in the Paraíba do Sul river, in 1998/99. In x-axis $=1:$ Z I; 2: Z II; 3: Z III.

several organic synthetic materials. Warwick (1986) has suggested that relationship between abundance and biomass species curves can indicate pollution-induced stress. Where biomass curves lies above the abundance curve the assemblage is not affected by pollution; where the two curves cross one another, the first stages of pollution-induced occur; on the other hand, where the abundance curve lies above the biomass curve the assemblage is from a grossly polluted habitat. Such patterns were confirmed in this study by the $A B C$ index confirming Z II as the most stressed zone.

The $K$-dominance and geometric class have also been used as indicator of pollution stress. The unstressed sites show steep curves with many rare species and few common species in geometric classes, whereas stressed sites show few rare species and dominance by a few highly common species (Gray, 1989). In this study, geometric classes showed a recovery capacity for Z III when compared to Z I and II. In $\mathrm{Z}$ III there was higher number of rare species and lower number of common species.

Deteriorating water quality is among the major factors contributing to the disappearance of some species in many rivers and streams. Karr et al. (1985), Ganasan \& Hughes (1998), SotoGalera et al. (1998), Allen et al. (1999) and Waite \& Carpenter (2000) found that pollution effect reflected decreasing richness at community and population level. At the community level, pollution reduces both species diversity and abundance. Only cer- 
tain species and only few individuals can survive in pollution and, thus, polluted habitats are poorer in species richness.

Indications of organic enrichment were showed in Z II, as indicated by high abundance of common species, and a lesser stressed situation in both upstream and downstream zones. Thus, water quality conditions seem to be a major barrier for the distribution of sensitive fish species in the rio Paraíba do Sul. Similar pattern was found by Gafny et al. (2000); Gregory et al. (1991); Bryce et al. (1999) and Araújo et al. (2003) who related habitat condition to fish assemblage structure in rivers receiving domestic effluent. The shape of the relationship between rivers response variable and a measure of stress likely depends mutually on the sensitivity of the response variable and mode of action of the environmental stressor. Nonlinear responses are expected whenever the species in question, or the majority of species, exhibit a sensitivity threshold to a particular stress, such as frequency or magnitude of pollution (Norris \& Thoms, 1999; Allan, 2004). Such study reported hypothetical relationship depicting possible responses of streams or rivers biological condition (taxon richness, assemblage similarity) to a gradient of increasing environmental stress. In the study case, it is difficult to assess the relationship between anthropogenic gradient and biological condition since no direct parameter of this first gradient was measured.

Another feature that causes decreasing ichthyofauna diversity is habitat degradation (Angermeier \& Karr, 1984; Karr et al., 1985; Li et al., 1987; Rutherford et al., 1987; Allan et al., 1997; Allan, 2004) such as margins erosion and destruction of habitats that are used as shelter and reproduction sites for large number of species. This situation is very common in the rioParaíba do Sul, as result of the increasing urban pressure. More studies of this kind are needed to determine whether physical improvements in the rio Paraíba do Sul condition are associated to fish assemblages composition and structure. Furthermore, dam construction obstructing the natural river course also contributes to decreasing fish abundance and diversity. Further analyses of the species present at the longitudinal the dams plus better knowledge of life histories are required to substantiate this hypothesis. However, given our knowledge of how dams and reservoirs alter lotic fish assemblages (Agostinho et al., 2000; Bowen et al., 1996; Dieterman et al., 2004; Pringle et al., 2000; Quist et al., 2004; Schiemer, 2000; Schmutz et al. 2000) we believe that habitat fragmentation is also contribution to river alterations. The low species richness at zone I is probably linked to this kind of alteration.

According to Gray (1989) three changes occur in the fish community structure as result of stressors: decreasing diversity, dominance of opportunists and reduction in size of dominant species. He also mentioned that there are changes in community structure as the stressor effect: common species are dominant in the first stages of impact; changes in the mean size are the second stage; the third stage is characterized by reduction of diversity. In this work it was found a still high diversity in the study area where 51 species were re- corded although this community has been dominated by few common species, specially at the most impacted Z II, corroborating the rio Paraíba do Sul fish community could be in the first stage of alteration. However, this interpretation of this information remains highly subjective and more studies are needed.

Some of the founds in this work seems to corroborate those founds by Araújo (1998) and Araújo et al., (2003) which adapted and developed the Index of Biotic Integrity (IBI) for this area, and reported that Barra Mansa and Volta Redonda reaches were the most impacted zones being classified as Very Poor, while Barra do Piraí reaches, located some $40 \mathrm{~km}$ downstream Volta Redonda, as Poor, indicating the river recovering capacity downstream the impacted area.

There is a great concern on the ecosystems integrity based on species as taxonomic functional unit, since biological diversity is decreasing and resources conservation often are inadequate. Winemiller (1995) reported that components and structure resilient mean that all organism and decedents should obtain some success by nutrition, growth, survive and reproduction process. In the studied reaches of the rio Paraíba do Sul, the use of biological indicator in response to environmental degradation was better succeed when compared to traditional physicochemical measurements. According to Metcalfe (1989), physicochemical measurements give a picture of the moment when they are collected; therefore it is necessary larger number of analyses to obtain robust and suitable tendencies. On the other hand, biological measurements are efficient to assess non-point source pollution (diffuse pollution), which must be considered in regional scales (Pratt \& Coler, 1976; De Pauw \& Vanhooren, 1983; karr et. al., 1986). Our results depict signals of alteration in fish assemblages at Z I, followed by a most evident polluted section at Z II, followed by a recovery capacity of the river at Z III. Further analyses to detect the underline causes of this pattern are required to obtain a more detailed relationship between the environmental constraints and species occurrence.

\section{Acknowledgements}

This paper is a portion of the first author's Master Dissertation submitted to Course of Animal Biology of the University Federal Rural of Rio de Janeiro. This research was partially financed by CAPES - Brazilian Agency for Trainee Third Level Personal - supporter the first author with scholarship and by FAPERJ - Rio de Janeiro State Research Support Foundation.

\section{Literature Cited}

Agostinho, A. A., S. M. Thomaz, C. V. Minte-Vera \& K. O. Winemiller. 2000. Biodiversity in the high Paraná river floodplain. In: B. Gopal, W. J. Junk \& J. A. Davis (eds.). Biodiversity in Wetlands: Assessment, Function and Conservation. Backhuys, Leiden, The Netherlands: 89-118.

Allan, J. D., D. L. Erickson \& J. Fay. 1997. The influence of catchment land use on stream integrity across multiple spatial scales. Freshwater Biology, 37: 149-161. 
Allan, J. D. 2004. Landscapes and riverscapes: the influence of land use on stream ecosystems. Annual Review Ecology Systematics, 35: 257-284.

Allen, A. P., T. R. Whittier, D. P. Larsen, P. R. Kaufmann, R. J. O'Connor, R. M. Hughes, R. S. Stemberger, S. S. Dixit, R. O. Brinkhurst, A. T. Herlihy \& S. G. Paulsen. 1999. Concordance of taxonomic composition patterns across multiple lake assemblages: effects of scale, body size, and land use. Canadian Journal of Fisheries and Aquatic Sciences, 56: 2029-2040.

Andrews, M. J. \& D. G. Rickard. 1980. Rehabilitation of the Inner Thames Estuary. Marine Pollution Bulletin, 11: 327-332.

Angermeier, P. L. \& J. R. Karr. 1984. Relationships between woody debris and fish habitat in a small warmwater stream. Transactions of the American Fisheries Society, 113: 716-726.

Araújo, J. R. S. 1983. Projeto de biodetecção de tóxicos em sistemas fluviais de utilização em captação de água para sistemas públicos de abastecimento. Cadernos FEEMA, Série Congressos. 17/83 (DEPEA/DNH).

Araújo, F. G. 1996. Composição e estrutura da comunidade de peixes do médio e baixo rio Paraíba do Sul, RJ. Revista Brasileira Biologia, 56: 111-126.

Araújo, F. G. 1998. Adaptação do índice de integridade biótica usando a comunidade de peixes para o rio Paraíba do Sul. Revista Brasileira Biologia, 58: 547-558.

Araújo, F. G., W. P. Williams \& R. G. Bailey. 2000. Fish assemblages as indicators of water quality in the Middle Thames Estuary, England (1980-1989). Estuaries, 23: 305-317.

Araújo, F. G., I. Fichberg, B. C. T. Pinto \& M. G. Peixoto. 2001. Variações espaciais na assembléia de peixes do rio Paraíba do Sul (Barra Mansa, Barra do Piraí), Rio de Janeiro, Brasil. Revista Brasileira Zoologia, 18: 483-492.

Araújo, F. G., I. Fichberg, B. C. T. Pinto \& M. G. Peixoto. 2003. A preliminary index of biotic integrity for monitoring condition of the Rio Paraíba do Sul, Southeast Brazil. Environmental Management, 32: 516-526.

Barbiére, E. B. \& D. M. P. Kronemberg. 1994. Climatologia do litoral sul-sudeste do Estado do Rio de Janeiro. Cadernos de Geociências, Rio de Janeiro, 12: 57-73.

Bowen, Z. H., M. C. Freeman \& D. L. Watson. 1996. Index of biotic integrity applied to a flow-regulated river system. Proceedings Annual Conference Southeastern Association Fish and Wildlife Agencies, 50: 26-37.

Bryce, S. A., D. P. Larsen, R. M. Hughes \& P. R. Kaufmann. 1999. Assessing relative risks to aquatic ecosystems: a mid-Appalachian case study. Journal of the American Water Resources Association, 35: 23-36.

Carvalho, C. E. V. \& J. P. M. Torres. 2002. The ecohydrology of the Paraíba do Sul river, Southeast Brazil. In: McClain, M. E. (ed), The Ecohydrology of South American Rivers and Wetlands. The IAHS Series of Special Publications, Venice, Italy: 179-191.

Coeck, J., A. Vandelannoote, R. Yseboodt \& R. F. Verheyen. 1993. Use of the abundance biomass method for comparison of fish communities in regulated and unregulated lowland rivers in Belgium. Regulated Rivers-Research \& Management, 8: 73-82.

CONAMA (Conselho Nacional de Meio Ambiente). 1986. Resolução No . 20, 18 June 1986. Ministério do Meio Ambiente, Brasília. Pp:1-16. Available at: www.mma.gov.br/port/conama/res/res86/ res2086.html

De Pauw, N \& G. Vanhooren. 1983. Method for biological quality assessment of watercouses in Belgium. Hydrobiologia, 100: 153-168

Dieterman, D. J. \& D. L. Galat. 2004. Large-scale factors associated with sicklefin chub distribution in the Missouri and lower
Yellowstone Rivers. Transactions of the American Fisheries Society, 133: 577-587.

DNAEE (Departamento Nacional de Águas e Energia Elétrica). 1983. Boletim Fluviométrico F-5.02, Bacia do rio Paraíba do Sul. Brasília, Distrito Federal.

Edds, D. R. 1993. Fish assemblage structure and environmental correlates in Nepal's Gandaki river. Copeia, 48-60.

FEEMA. 1987. Qualidade das águas do estado do Rio de Janeiro, Brazil. Fundação Estadual de Engenharia e Meio Ambiente, Rio de Janeiro.

Gafny, S., M. Goren \& A. Gasith. 2000. Habitat condition and fish assemblage structure in a coastal Mediterranean stream (Yarqon, Israel) receiving domestic effluent. Hydrobiologia, 422/423: 319-330.

Ganasan, V. \& R. M. Hughes. 1998. Application of an index of biological integrity (IBI) to fish assemblages of the rivers Klan and Kshipra (Madhya Pradesh), India, Freshwater Biology, 40: 367-383.

García, C. B., L. O. D. Duarte \& V. Schiller. 1998. Demersal fish assemblages of the Gulf of Salamanca, Colombia (southern Caribbean Sea). Marine Ecology Progress Series, 174: 13-25.

Goldstein, R. M. 1981. Longitudinal succession in impact assessment of river system fish communities. Water Resources Bulletin, 17: 75-81.

Gray, J. S. \& T. H. Pearson. 1982. Objective selection of sensitive species indicative of pollution-induced change in benthic communities. I. Comparative methodology. Marine Ecology Progress Series, 9: 111-119.

Gray, J. S., M. R. K. R. Clarke, R. H. Green, T. H. Pearson, R. Rosenberg \& R. M. Warwick. 1988. Analysis of community attributes of the benthic macrofauna of Frierfjord/Langesundfjord and in a mesocosm experiment. Marine Ecology Progress Series, 46: 151-165.

Gray, J. S. 1989. Effects of environmental stress on species rich assemblages. Biology Journal Linnology Society, 37: 19-32.

Gregory, S. V., F. J. Swanson, W. A. McKee \& K. W. Cummins. 1991. An ecosystem perspective of riparian zones: focus on links between land and water. BioScience, 41: 540-551.

Hughes, R. M., S. G. Paulsen \& I. Stoddard. 2000. EMAP- Surface Waters: a national, multiassemblage, probability survey of ecological integrity in the U.S.A. Hydrobiologia, 422/423: 429-443.

Hydroscience Inc. 1977. The Paraíba do Sul River Water Quality Study. Technical Report 6, BRA-73/003. Toms River, New Jersey.

Karr, J. R. 1981. Assessment of biotic integrity using fish communities. Fisheries, 6: 21-27.

Karr, J. R., R. C. Heidinger \& E. H. Helmer. 1985. Effects of chlorine and ammonia from wastewater treatment facilities on biotic integrity. Journal of the Water Pollution Control Federation, 57: 912-915.

Karr, J. R., K. D. Fausch, P. L. Angermeier, P. R. Yant \& I. J. Schlosser. 1986. Assessing biological integrity in running waters: a method and its rationale. Illinois Natural History Survey Special Publication, 5: $28 \mathrm{p}$.

Karr, J. R., D. Allan \& A. C. Benke. 2000. River conservation in the United States and Canada: Science, Policy, and Practice. In: P. J. Boon, B. R. Davis \& G. E. Petts (eds.). Perspectives on River Conservation: Science, Policy, and Practice. John Wiley. Chichester, Global, 35 p.

Klein, R. D. 1979. Urbanization and stream quality impairment. Water Resources Bulletin, 15: 948-963. 
Krebs, C. J. 1985. Ecology. Harper \& Row, New York, 800 p.

Krebs, C. J. 1994. Ecology: The experimental analysis of distribution and abundance. $4^{\text {th }}$. Ed. Harper Collins College, New York, $881 \mathrm{p}$.

Lambshead, P. J. D., H. M. Platt \& K. M. Shaw. 1983. The detection of differences among assemblages of marine benthic species based on an assessment of dominance and diversity. Journal of Natural History, 17: 859-874.

Lammert, M. \& J. D. Allan. 1999. Assessing biotic integrity of streams: effects of scale in measuring the influence of land use/ cover and habitat structure on fish and macroinvertebrates. Environmental Management, 23: 257-270.

Li, H. W., C. B. Schreck, C. E. Bond \& E. Rexstad. 1987. Factors influencing changes in fish assemblages of Pacific Northwest stream. Pp.193-202. In: Matthews, W.J. \& D. C. Heins (eds.), Community and evolutionary ecology of North American stream fishes. University of Oklahoma Press, Norman.

Meador, M. R. \& R. M. Goldstein. 2003. Assessing water quality at large geographic scales: relations among land use, water physicochemistry, riparian condition, and fish community structure. Environmental Management, 31: 504-517.

Meire, P. M. \& J. Dereu. 1990. Use of the abundance/biomass comparison method for tetecting environmental stress: some considerations based on intertidal macrozoobenthos and bird communities. Journal of Applied Ecology, 27: 210-223.

Metcalfe, J. L. 1986. Biological water quality assessment of running water based on macroinvertebrates communities: history and present status in Europe. Environmental Pollution, 60: 101-139.

Miller, K. L. \& 13 co-authors. 1988. Regional application of an index of biotic integrity for use in water resource management. Fisheries, 13: 12-38.

Nelson, J. S. 1994. Fishes of the world. John Wiley \& Sons, Inc. ${ }^{\text {rd }}$.Ed. New York, 600 p.

Norris, R. H. \& M. C. Thoms. 1999. What is river health? Freshwater Biology, 41: 197-209.

Odum, E. P. 1969. Ecologia. São Paulo, Pioneira, 201p.

Pagola-Carte, S. 2004. ABC method and biomass size spectra: what about macrozoobenthic biomass on hard substrata? Hydrobiologia, 527: 163-176.

Paller, M. H., M. J. M. Reichert \& J. M. Dean. 1996. Use of fish communities to assess environmental impacts in South Carolina costal plain streams. Transactions of the American Fisheries Society, 125: 633-644.

Pfeiffer, W. C., M. Fiszman, O. Malm \& J. M. Azcue. 1986. Heavy metal pollution in the Paraíba do Sul River, Brazil. Science of the Total Environmental, 58: 73-79.

Pratt, J. M. \& R. A. Coler. 1976. A procedure for the routine biological evaluation of urban runoff in small rivers. Water Research, 10: 1019-1025.

Pringle, C. M, M. C. Freeman \& B. J. Freeman. 2000. Regional effects of hydrologic alterations on riverine macrobiota in the new world: tropical-temperate comparisons. BioScience, 50: 807-823.

Quist, M. C., W. A. Hubert \& F. J. Rahel. 2004. Relations among habitat characteristics, exotic species, and turbid-river cyprinids in the Missouri River drainage of Wyoming. Transactions of the American Fisheries Society, 133: 727-742.
Reis, R. E., S. O. Kullander \& C. J. Ferraris, Jr. 2003. Check list of the freshwater fishes of South and Central America. Porto Alegre, Edipucrs, 729 p.

Rosenberg, D. M. \& V. H. Resh. 1993. Freshwater biomonitoring and benthic macroinvertebrates. Chapman and Hall, New York, $488 \mathrm{p}$.

Roth, N. E., J. D. Allan \& D. L. Erickson. 1996. Landscape influences on stream biotic integrity assessed at multiple spatial scales. Landscape Ecology, 11: 141-156.

Roughgarden, J. 1974. Species packing and the competition function with illustrations from coral reef fish. Theoretical Population Biology, 5: 163-186.

Rutherford, D. A., A. A. Echelle \& O. E. Maughan. 1987. Changes in the fauna of the Little River drainage, southeastern Oklahoma, 1948-1955 to 1981-1982: a test of the hypothesis of environmental degradation. Pp 178-183. In: Matthews W. J. \& D. C. Heins (eds.). Community and evolutionary ecology of North American stream fishes. University of Oklahoma Press, Norman.

Schleiger, S. L. 2000. Use of an index of biotic integrity to detect the effects of land use on stream fish communities in West-Central Georgia. Transactions of the American Fisheries Society, 129: 118-133.

Schiemer, F. 2000. Fish as indicators for the assessment of ecological integrity of large rivers. Hydrobiologia, 423: 271-278.

Schmutz, S., M. Kaufmann, B. Vogel, M. Jungwirth \& S. Muhar. 2000. A multi-level concept for fish-based, river-type-specific assessment of ecological integrity. Hydrobiologia, 423: 279-289.

Scott, M. C. A \& L. W. Hall Jr. 1997. Fish assemblages as indicators of environmental degradation in Maryland coastal plain streams. Transactions of the American Fisheries Society, 126: 349-360.

Shepherd, G. J. 2001. Fitopac 1. Manual do usuário. Campinas, Universidade de Campinas, $93 \mathrm{p}$.

Soto-Galera, E., E. Díaz-Pardo, E. López-López \& J. Lyons. 1998. Fish as indicators of environmental quality in the Río Lerma Basin, México. Aquatic Ecosystem Health \& Management, 1: 267-276.

Steedman, R. J. 1988. Modification and assessment of an index of biotic integrity to quantify stream quality in southern Ontario. Canadian Journal of Fisheries and Aquatic Sciences, 45: 492-501.

US Environmental Protection Agency. 1999. National recommended water quality criteria - correction: EPA 822/Z-99-001. Washington, DC.

Waite, I. R. \& K. D. Carpenter. 2000. Associations among fish assemblage structure and environmental variables in Willamette Basin streams, Oregon. Transactions of the American Fisheries Society, 129: 754-770.

Warwick, R. M. 1986. A new method for detecting pollution effects on marine macrobenthic communities. Marine Biology, 92: 557-562.

Winemiller, K. O. 1995. The structural and functional aspects of fish diversity. Bulletin Francais de la Peche et de la Pisciculture. 337/338/33: 23-45.

Received June 2005 Accepted May 2006 